\title{
Cordia oncocalyx (Allemão) Baill. (Boraginaceae) Chemical Composition and Alelopathic Effect Against Weeds
}

\author{
Danúbio Lopes da Silva ${ }^{1}$, Marcos Aurélio Figueiredo dos Santos ${ }^{2}$, Jose Weverton Almeida Bezerra ${ }^{3}$, \\ Cícero dos Santos Leandro ${ }^{2}$, Maria Daniele Pereira Rodrigues ${ }^{2}$ Ana Karolina Fernandes Silva ${ }^{2}$, \\ Arycelle Alves de Oliveira ${ }^{1}$, Natália Barbosa Campos ${ }^{1}$, Kyhara Soares Pereira ${ }^{1}$, Janete de Souza Bezerra ${ }^{2}$, \\ Aline Augusti Boligon ${ }^{4} \&$ Maria Arlene Pessoa da Silva ${ }^{1,2}$ \\ ${ }^{1}$ Master's Program in Molecular Bioprospecting, Cariri Regional University, Brazil \\ ${ }^{2}$ Department of Biological Sciences, Cariri Regional University, Brazil \\ ${ }^{3}$ Master's Program in Plant Biology, Federal University of Pernambuco, Brazil \\ ${ }^{4}$ Federal University of Santa Maria, Brazil \\ Correspondence: Danúbio Lopes da Silva, Department of Biological Sciences, Regional University of Cariri, \\ Brazil. E-mail: danubio_ls@hotmail.com
}

Received: June 9, 2018

doi:10.5539/jas.v10n12p262
Accepted: August 21, 2018

Online Published: November 15, 2018

\begin{abstract}
Through secondary metabolism, plants produce chemical compounds which when released into the environment can have effects on other species, such effect is called allelopathy. In this research we evaluated the Cordia oncocalyx (Boraginaceae) allelopathic potential against two weed species, Cenchrus echinatus and Calotropis procera, as well as quantified its phenolic compounds using HPLC-DAD. The experimental design was completely randomized with six treatments and one control group (distilled water). Each treatment consisted of four replicates with 25 seeds each, totaling 100 seeds per treatment. The variables analyzed were: germinating potential, germination velocity and seedling development. The hot and cold infusion extracts were prepared with $50 \mathrm{~g}$ of each of the three parts of the donor plant (bark, leaves and roots) immersed in $500 \mathrm{ml}$ of distilled water at $100{ }^{\circ} \mathrm{C}$ (hot infusion) and $25^{\circ} \mathrm{C}$ (cold infusion). The experiments were mounted in Petri dishes having substrate filter paper embedded in $3 \mathrm{~mL}$ of the extracts (treatments) and conducted in a germination chamber. Hot and cold infusion extracts of the $C$. oncocalyx leaves, barks and roots presented allelopathic activity on C. echinatus and C. procera germination and development, with the hot bark extract promoting such effect with a greater intensity. The allelopathic effect observed may be due to the presence of allelochemicals such as caffeic acid, quercentin and kaempferol present in C. oncocalyx leaves, barks and roots.
\end{abstract}

Keywords: allelochemicals, Auxemma oncocalyx, bioherbicide, phytochemistry

\section{Introduction}

The allelopathy, positive or negative interference of donor plant species on germination, initial growth or development of host species present in the same environment (Alves et al., 2004) is attributed to allelochemicals or phytochemicals (Rice, 1984; Ferreira \& Borghetti, 2004; Rizzardi et al., 2008). However, it is important to note that in the present study, it was found that the presence of plant residues in the soil was associated with a higher level of plant depletion. Such allelochemicals may affect respiration, photosynthesis, enzymatic activity, water relations, stomatal opening, hormone levels, mineral availability, cell division and stretching, structure and permeability of membranes and cell walls (Zeng et al., 2010).

In the last decades, researches have been carried out with the objective of identifying allelopathic properties in species with agroforestry and silvipastoral potentialities (Souza Filho et al., 2006), such as Boraginaceae species. In this work the effects of allelopathic compounds are verified by means of aqueous and/or alcohol extracts obtained from roots, stems and leaves (Emilio et al., 2007).

In the literature are attributed to leaves, barks and roots of the species Cordia one of the largest and most important genera of the Boraginaceae family, a great diversity of biological and pharmacological activities such as: antimicrobial, antifungal, larvicidal, antiinflammatory and analgesic (Medeiros et al., 2007; Matias et al., 2013), which may be related to different classes of secondary metabolites present in them. For the species of the family 
quinones, hydroquinones, terpenoids, terpene alcohols, phenolic compounds, flavonoids, saponins, tannins, steroids and nitrogen compounds are mentioned (Barroso et al., 2002), many of which are responsible for the observed allelopathic activity. For Cordia oncocalyx the occurrence of phenolic compounds, flavonoids and tannins was confirmed.

Due to these compounds the allelopathic action attributed to several species of plants has been analyzed with a view to the control of invasive species that promote alteration in the natural ecosystems and reduce the plant diversity causing displacement of native species by the allelopathic inhibition of germination or growth via phytotoxic chemical release (Peres et al., 2004; Maraschin-Silva \& Aquila, 2006).

Thus, research on allelopathy may lead to the production of bioherbicides to be used in weed control (Oliveira et al., 2012), providing a viable alternative for the control of species that affect crops, and replacing agricultural industrial inputs with biological herbicides, resulting in balanced pastures and free of pesticides. At the same time they would also prevent serious damage to nature such as degradation and contamination of the water table due to the increasing use of chemicals (Carvalho et al., 2002).

Considering these aspects, the objective of this study was to verify the effect of extracts by hot and cold infusion of leaves, stem bark and roots of Cordia oncocalyx on the germination and initial development of the plants of Cenchrus echinatus and Calotropis procera, and to identify the secondary compounds present in said extracts responsible for the observed effects.

\section{Materials and Methods}

\subsection{Species Studied and Botanical Material Collection}

Cordia oncocalyx (Allemão) Baill. (Boraginaceae), synonym for Auxemma oncocalyx (Allemão) Taub., is an endemic species of the Caatinga, a seasonally dry tropical forest, where the species is known as "pau-branco", "louro-branco", "pau branco-preto" and "pau branco-do-sertão" (Gottschling \& Miller, 2006; Carvalho, 2008). Its wood is used in the firewood and good quality charcoal production. The bark is astringent and used as a medicine in baths for the treatment of sores and wounds as well as in the ectoparasitoses treatment in domestic animals. The flowers are rich in allantoin and can be used in ointments or as dyes and cooking for local wound, ulcer and burn treatment (Guimarães et al., 2013). This species was chosen because it presents a range of chemical constituents that may present activities in other biological organisms, such as in seeds and seedlings (Ferreira et al., 1999; Marques et al., 2000).

Leaves, bark, and C. oncocalyx roots were collected from the city of Crato, Ceará, Brazil (S $07^{\circ} 13^{\prime} 52^{\prime \prime}$ and W $\left.039^{\circ} 24^{\prime} 38^{\prime \prime}\right)$. Part of the collected botanical material was herborized, identified and incorporated into the collection of the Caririense Dárdano de Andrade-Lima Herbarium (HCDAL) of the Regional University of Cariri (URCA), registered under voucher Silva, D. L. et al. 12,784.

Regarding the recipient species, a monocotyledon, Cenchrus echinatus L. (Poaceae) and an eudicotyledon, Calotropis procera (Aiton) W. T. Aiton, (Apocynaceae), known as "carrapicho" and "ciumeira", respectively, were selected. The first is a grass seed that develops spontaneously throughout Brazil, especially in plant cultivation areas with agronomic interest. The same is undesirable because it presents in its fruits spinescent structures which aid in its dispersion, however these end up hurting people (Moreira \& Bragança, 2011). Moreover, with $C$. echinatus infestation there is a considerable release of allelochemicals in the environment which negatively interfere with other plants (Ahmed et al., 2016; Favaretto et al., 2018). As for C. procera, this is an exotic species in Brazil introduced as an ornamental plant which eventually became a weed throughout most of the territory. This weed species is undesirable both because it presents toxicity to humans, but also because it affects pasture productivity (Menge et al., 2017). In this way, mature seeds from these weeds were collected from the city of Crato, Ceará, Brazil to perform the bioassays.

\subsection{Plant Extract and Bioassay Preparations}

Two $50 \mathrm{~g}$ portions of each $C$. oncocalyx (donor species) part (leaves, bark and roots) were used for hot and cold extract production. The two $50 \mathrm{~g}$ portions from each organ were packed separately into six beakers. With each plant part a hot $\left(500 \mathrm{~mL}\right.$ of boiling distilled water) and a cold $\left(500 \mathrm{~mL}\right.$ of distilled water at $\left.25^{\circ} \mathrm{C}\right)$ treatment were performed. The material extraction period was 30 minutes. After that time, the solutions and solids were triturated for 1 minute and filtered for retention of all fibrous material, followed by centrifugation at $3000 \mathrm{rpm}$ for 10 minutes. The extracts were evaluated for their osmotic levels and hydrogenation potential (Santos et al., 2015). 
The experimental design was completely randomized with seven treatments: hot $\left(100{ }^{\circ} \mathrm{C}\right)$ leaf, bark and root extracts and cold $\left(25^{\circ} \mathrm{C}\right)$ leaf, bark and root extracts, as well as a control (distilled water) with four C. echinatus 25 seed replicates and four $C$. procera 25 seed replicates. In each experimental plot (Petri dish) with a sheet of filter paper, previously oven sterilized at $105 \pm 3{ }^{\circ} \mathrm{C}$, with $3 \mathrm{~mL}$ of the crude extract added to them using a pipette were placed on the seeds. The appropriately sterilized Petri dishes were conditioned in a BOD type germination chamber with a temperature of $25^{\circ} \mathrm{C}$ and a $12 \mathrm{~h}$ photoperiod for five days for C. echinatus and seven days for $C$. procera. The germinated seed count was performed every 24 hours.

\subsection{Chemical, Apparatus and General Procedures}

All chemical were of analytical grade. Methanol, phosphoric acid, gallic acid, ellagic acid, chlorogenic acid and caffeic acid were purchased from Merck (Darmstadt, Germany). Luteolin, rutin, quercetin and kaempferol were acquired from Sigma Chemical Co. (St. Louis, MO, USA). High performance liquid chromatography (HPLC-DAD) was performed with a Shimadzu Prominence Auto Sampler (SIL-20A) HPLC system (Shimadzu, Kyoto, Japan), equipped with Shimadzu LC-20AT reciprocating pumps connected to a DGU 20A5 degasser with a CBM 20A integrator, SPD-M20A diode array detector and LC solution 1.22 SP1 software.

Cordia oncocalyx samples at a concentration of $10 \mathrm{mg} / \mathrm{mL}$ were injected by means of a model SIL-20A Shimadzu Auto sampler. Separations were carried out using Phenomenex $\mathrm{C}_{18}$ column $(4.6 \mathrm{~mm} \times 250 \mathrm{~mm} \times 5$ $\mu \mathrm{m}$ particle size). The mobile phase was water with $1 \%$ phosphoric acid $(\mathrm{v} / \mathrm{v})$ (solvent A) and HPLC grade methanol (solvent B) at a flow rate of $0.6 \mathrm{~mL} / \mathrm{min}$ and injection volume $40 \mu \mathrm{L}$. The composition gradient was: $5 \%$ solvent B reaching $15 \%$ at $10 \mathrm{~min} ; 30 \%$ solvent B at $35 \mathrm{~min}, 65 \%$ solvent B at $50 \mathrm{~min}$ and $98 \%$ solvent B at $65 \mathrm{~min}$, followed by $70 \mathrm{~min}$ at isocratic elution until $75 \mathrm{~min}$. At $80 \mathrm{~min}$ the gradient reached the initial conditions again, following the method described by Adefegha et al. (2016) with slight modifications. The sample and mobile phase were filtered through $0.45 \mu \mathrm{m}$ membrane filter (Millipore) and then degassed by ultrasonic bath prior to use. Stock solutions of standards references were prepared at a concentration range of $0.030-0.500$ $\mathrm{mg} / \mathrm{mL}$. Quantifications were carried out by integration of the peaks using the external standard method, at 254 $\mathrm{nm}$ for gallic and ellagic acids; $327 \mathrm{~nm}$ for chlorogenic acid and caffeic acid; and 366 for luteolin, quercetin, rutin and kaempferol. The chromatography peaks were confirmed by comparing its retention time with those of reference standards and by DAD spectra $(200$ to $600 \mathrm{~nm})$. All chromatography operations were carried out at ambient temperature and in triplicate.

\subsection{Variables Analyzed}

\subsubsection{Germination Test}

Germination was evaluated every 24 hours, during five days for Cenchrus echinatus L and seven days for Calotropis procera (Aiton) W. T. Aiton, considering seeds with primary root length $\geq 2 \mathrm{~mm}$ as germinated.

\subsubsection{Germination Velocity Index}

The Germination Velocity Index (GVI) was calculated according to Maguire (1962) with a daily log of the number of seeds germinated by means of the following equation:

$$
\mathrm{IVG}=\mathrm{G} 1 \mathrm{~N} 1+\mathrm{G} 2 / \mathrm{N} 2+\ldots+\mathrm{Gn}
$$

Where,

$\mathrm{G} 1, \mathrm{G} 2, \mathrm{Gn}=$ number of germinated seeds in the first, second and last counts; N1, N2, Nn = number of sowing days in the first, second and last count.

\subsubsection{Seedling Development}

After five days of $C$. echinatus germination and seven days C. procera germination, five seedlings from each plate were randomly chosen for caulicle and radicle biometry.

\subsection{Statistical Analysis}

For data statistics, the PRISMA program version 6.0, with an analysis of variance (ANOVA) and mean comparison using Regression Analysis or using Tukey's Test and 5\% probability was used. Differences between HPLC groups were assessed by an analysis of variance model and Tukey's test. The level of significance for the analyzes was set to $\mathrm{p}<0.05$. These analyzes were performed by using the free software $\mathrm{R}$ version 3.1.1 (R Core Team, 2014). 


\section{Results and Discussion}

\subsection{High Efficiency Liquid Chromatography Analysis with Diode Array Detector (HPLC-DAD)}

The HPLC profile of the Cordia oncocalyx extracts were also acquired, with their analysis shown in (Figura 1). The samples contain other minor compounds in addition to gallic acid (retention time- $t_{R}=10.19$ min, peak 1 ), chlorogenic acid $\left(t_{R}=21.53\right.$ min, peak 2$)$, caffeic acid $\left(t_{R}=25.04\right.$ min, peak 3$)$, ellagic acid $\left(t_{R}=31.97\right.$ min, peak 4), rutin $\left(t_{R}=38.26\right.$ min, peak 5), quercetin $\left(t_{R}=49.07\right.$ min, peak 6), kaempferol $\left(t_{R}=55.13\right.$ min, peak 7) and luteolin $\left(\mathrm{t}_{\mathrm{R}}=64.35 \mathrm{~min}\right.$, peak 8$)$.

According to the HPLC-DAD spectra and (Table 1), the bark extracts present quercetin as its major polyphenolic compound, with the hot extract having a concentration of $5.97 \pm 0.01 \mathrm{mg} / \mathrm{g}$ and the cold extract $3.26 \pm 0.07 \mathrm{mg} / \mathrm{g}$. In addition, chlorogenic acid, caffeic acid and luteolin were not present in the cold extract, however they were present in the hot extract. As for the leaves, their hot and cold extracts had quercetin $(4.647 \pm 0.03 \mathrm{mg} / \mathrm{g})$ and luteolin $(3.07 \pm 0.04 \mathrm{mg} / \mathrm{g})$ as its major compounds. The presence of chlorogenic acid and kaempferol were not identified in any of the leaf extracts, whereas gallic acid and rutin were only present in hot extracts at concentrations of $0.94 \pm 0.01 \mathrm{mg} / \mathrm{g}$ and $0.58 \pm 0.01 \mathrm{mg} / \mathrm{g}$, respectively. As for root extracts, caffeic acid $(6.05 \pm 0.03$ $\mathrm{mg} / \mathrm{g})$ and kaempferol were identified as the major hot extract constituents, whereas quercetin $(3.90 \pm 0.01 \mathrm{mg} / \mathrm{g})$ was the major constituent of the cold extract. Still regarding this plant part, gallic acid as well as luteolin were not identified.
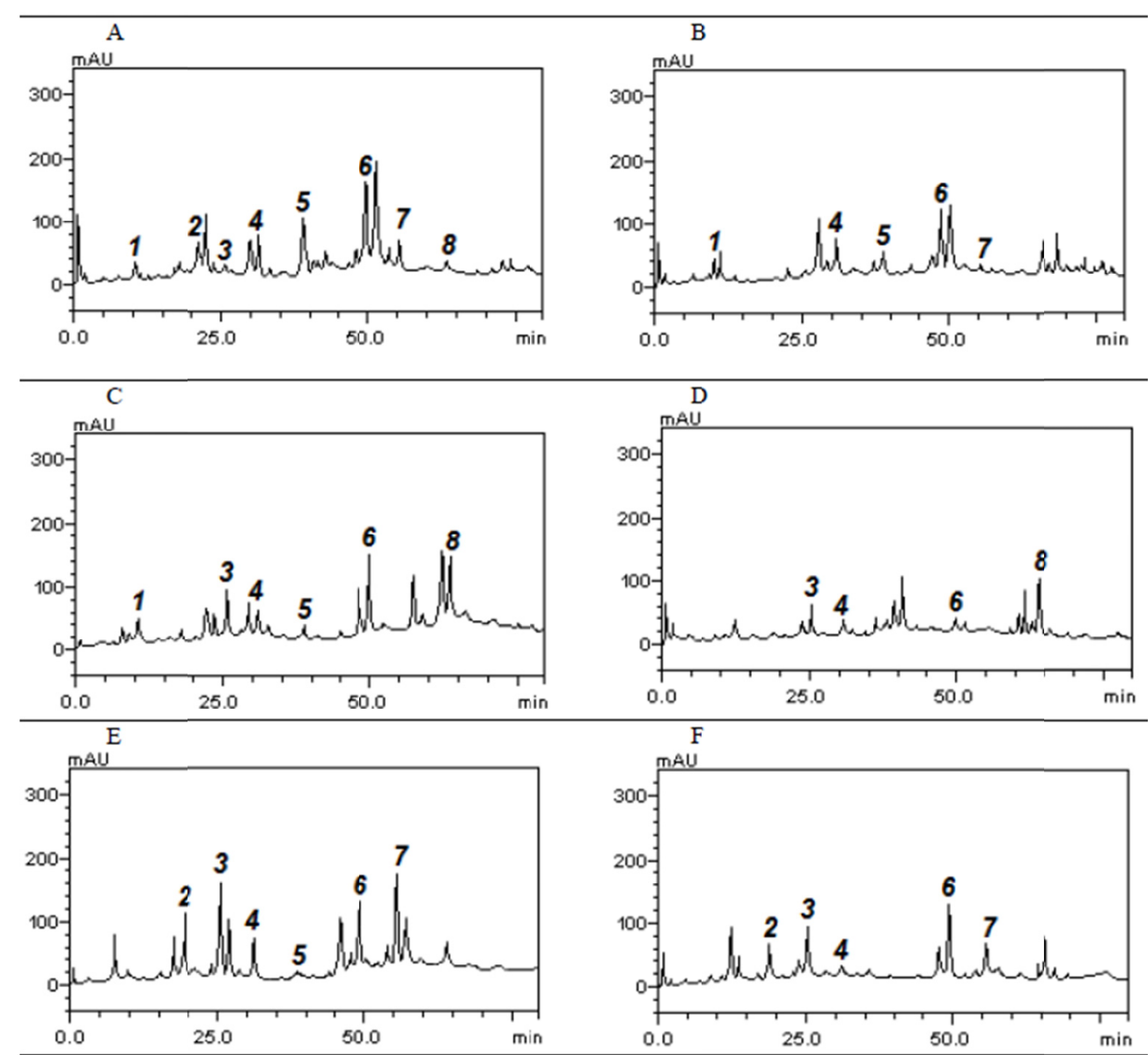

Figure 1. Representative high performance liquid chromatography profile of the Cordia oncocalyx extracts. A: Hot bark extract; B: Cold bark extract; C: Hot leaf extract; D: Cold leaf extract; E: Hot root extract; F: Cold root extract; Gallic acid (peak 1), chlorogenic acid (peak 2), caffeic acid (peak 3), ellagic acid (peak 4), rutin (peak 5), quercetin (peak 6), kaempferol (peak 7) and luteolin (peak 8) 
Table 1. Chemical components found in the extracts from different Cordia oncocalyx parts

\begin{tabular}{lllllll}
\hline Compounds & Hot bark extract & Cold bark extract & Hot leaf extract & Cold leaf extract & Hot root extract & Cold root extract \\
\hline Gallic acid & $-0.83 \pm 0.02 \mathrm{a}$ & $0.71 \pm 0.05 \mathrm{a}$ & $0.94 \pm 0.01 \mathrm{a}$ & - & - & - \\
Chlorogenic acid & $1.72 \pm 0.01 \mathrm{~b}$ & - & - & - & $3.54 \pm 0.01 \mathrm{a}$ & $1.78 \pm 0.03 \mathrm{a}$ \\
Caffeic acid & $0.19 \pm 0.05 \mathrm{c}$ & - & $2.08 \pm 0.07 \mathrm{~b}$ & $1.05 \pm 0.03 \mathrm{a}$ & $6.05 \pm 0.03 \mathrm{~b}$ & $2.09 \pm 0.01 \mathrm{~b}$ \\
Ellagic acid & $1.69 \pm 0.03 \mathrm{~b}$ & $1.94 \pm 0.04 \mathrm{~b}$ & $0.91 \pm 0.04 \mathrm{a}$ & $0.62 \pm 0.05 \mathrm{~b}$ & $1.83 \pm 0.01 \mathrm{c}$ & $0.62 \pm 0.05 \mathrm{c}$ \\
Rutin & $3.53 \pm 0.01 \mathrm{~d}$ & $1.58 \pm 0.01 \mathrm{c}$ & $0.58 \pm 0.01 \mathrm{c}$ & - & $0.36 \pm 0.01 \mathrm{~d}$ & - \\
Quercetin & $5.97 \pm 0.01 \mathrm{e}$ & $3.26 \pm 0.07 \mathrm{~d}$ & $4.67 \pm 0.03 \mathrm{~d}$ & $0.58 \pm 0.01 \mathrm{~b}$ & $3.69 \pm 0.04 \mathrm{a}$ & $3.90 \pm 0.01 \mathrm{~d}$ \\
Kaempferol & $1.65 \pm 0.02 \mathrm{~b}$ & $0.15 \pm 0.03 \mathrm{e}$ & - & - & $6.11 \pm 0.02 \mathrm{~b}$ & $1.85 \pm 0.04 \mathrm{a}$ \\
Luteolin & $0.24 \pm 0.04 \mathrm{c}$ & - & $3.19 \pm 0.03 \mathrm{e}$ & $3.07 \pm 0.04 \mathrm{c}$ & - & -
\end{tabular}

Note. The results are expressed as mean \pm standard deviation (SD) of three determinations. Means followed by different letters differ from each other by Tukey's test $\mathrm{p}<0.05$.

\subsection{Germinability}

The hot $C$. oncocalyx bark extract significantly decreased the germination percentage of $C$. procera seeds ( $80 \pm 8.6 \%$ ) compared to the control group $(98 \pm 2.3 \%$ ) (Figure 2$)$. While the other $C$. oncocalyx extracts did not significantly affect $C$. procera germinability.

As for the monocotyledon host, $C$. echinatus, four $C$. oncocalyx extracts decreased germinability. The hot bark $(30 \pm 6.9 \%)$ and root $(39 \pm 3.8 \%)$ extracts were the most significant, followed by hot $(49 \pm 5.03 \%)$ and cold $(48 \pm 7.3 \%)$ leaf extracts, when compared to the control group (66 $15.14 \%)$ (Figure 2).

C. echinatus had the germination of its seeds inhibited in the presence of the extracts: hot and cold bark extracts, cold leaf and hot root C. oncocalyx extracts (Figure 3).

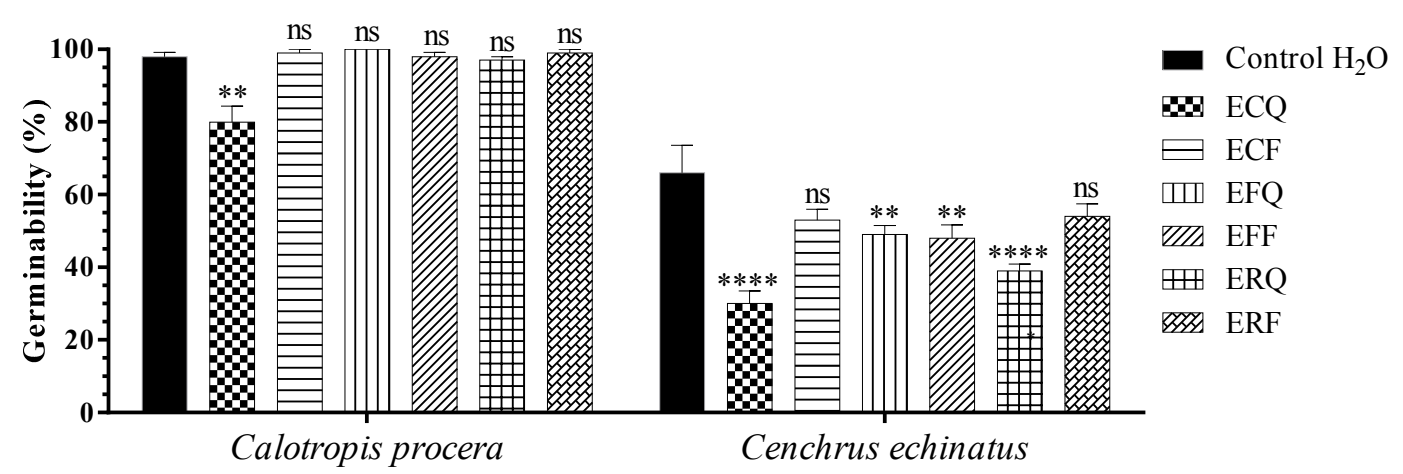

Figure 2. C. procera and C. echinatus germinability subjected to C. oncocalyx extracts

Note. Ns: no statistical significance when compared to the control group. $* * * *$ Statistical significance when compared to control. EQC (Hot Bark Extract), EFC (Cold Bark Extract), EQF (Hot Leaf Extract), EFF (Cold Leaf Extract), EQR (Hot Root Extract), EFR (Cold Root Extract). * Corresponds to negative allelopathic effect.

\subsection{Germination Velocity Index (GVI)}

The $C$. procera seed germination velocity indices were negatively affected when compared to the control $(8.12 \pm 0.17)$ by the hot $(6.22 \pm 0.18)$ and cold $(6.11 \pm 0.09)$ C. procera leaf extracts, however the hot bark extract was the one which most affected the GVI with a value of $4.49 \pm 0.64$ (Table 2). Unlike the $C$. procera GVI, the $C$. echinatus GVI subjected to $C$. oncocalyx extracts had a positive allelopathic effect, this effect being from hot leaf $(6.70 \pm 0.42)$ and cold root $(8,97 \pm 0.89)$ extracts. 
Table 2. Germination Velocity Index of Calotropis procera and Cenchrus echinatus against Cordia oncocalyx extracts

\begin{tabular}{lll}
\hline Extract & GVI (Calotropis procera) & GVI (Cenchrus echinatus) \\
\hline Control $\mathrm{H}_{2} \mathrm{O}$ & $8.12 \pm 0.17 \mathrm{a}$ & $4.37 \pm 1.02 \mathrm{a}$ \\
$\mathrm{EQC}$ & $4.49 \pm 0.64 \mathrm{~b}$ & $3.64 \pm 1.31 \mathrm{a}$ \\
$\mathrm{EFC}$ & $8.12 \pm 0.19 \mathrm{a}$ & $4.55 \pm 0.69 \mathrm{a}$ \\
$\mathrm{EQF}$ & $6.22 \pm 0.18 \mathrm{c}$ & $6.70 \pm 0.42 \mathrm{~b}$ \\
$\mathrm{EFF}$ & $6.11 \pm 0.09 \mathrm{c}$ & $4.60 \pm 0.59 \mathrm{a}$ \\
$\mathrm{EQR}$ & $8.32 \pm 0.21 \mathrm{a}$ & $5.16 \pm 0.23 \mathrm{ab}$ \\
EFR & $8.43 \pm 0.20 \mathrm{a}$ & $8.97 \pm 0.89 \mathrm{c}$ \\
\hline
\end{tabular}

Note. EQC (Hot Bark Extract), EFC (Cold Bark Extract), EQF (Hot Leaf Extract), EFF (Cold Leaf Extract), EQR (Hot Root Extract), EFR (Cold Root Extract). In each column, means followed by the same letter do not differ statistically from each other $(\mathrm{P} \leq 0.05)$.

\subsection{Seedling Development}

As for $C$. procera caulicle length development, the hot bark extract $(2.6 \pm 2.79 \mathrm{~mm})$, as well as the cold leaf extract $(4.2 \pm 3.6 \mathrm{~mm})$, significantly decreased the length of the structure when compared to the control $(18.8 \pm 1.78 \mathrm{~mm})$ (Figure 3). However, when evaluating C. procera radicle development, there was no reduction of the structure, rather a significant increase in their length when subjected to the cold bark extract $(32.05 \pm 4.44$ $\mathrm{mm})$, when compared to the control group $(20.1 \pm 2.4 \mathrm{~mm}$ ) (Figure 3).

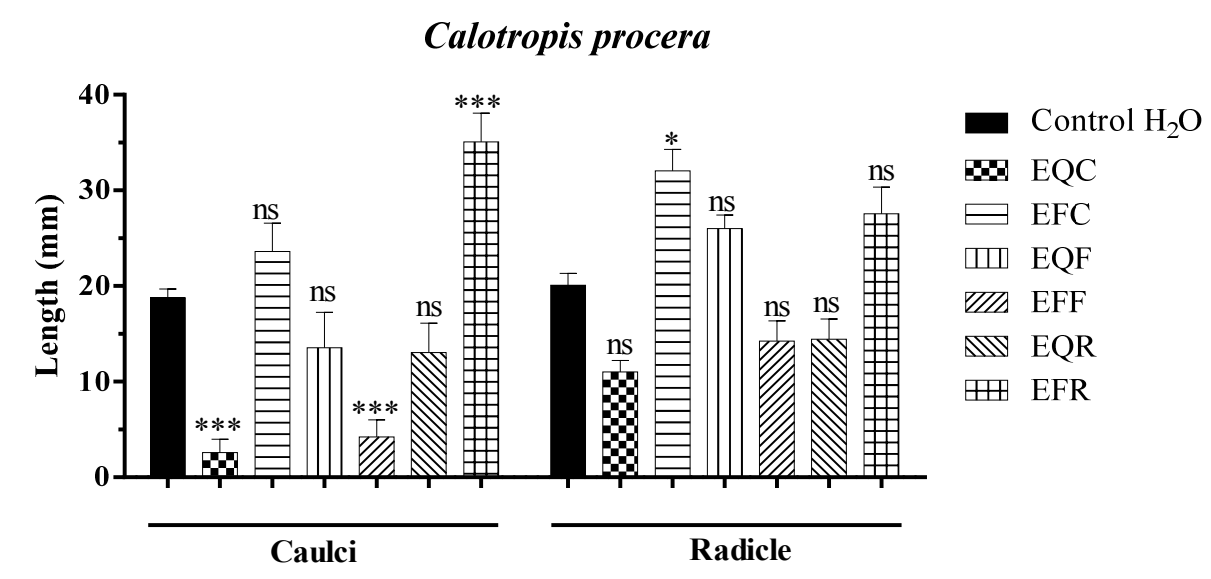

Figure 3. Caulicular and radicular $C$. procera seedling length subjected to $C$. oncocalyx extracts

Note. Ns: no statistical significance when compared to the control group. ${ }^{* * * *}$ Statistical significance when compared to control. EQC (Hot Bark Extract), EFC (Cold Bark Extract), EQF (Hot Leaf Extract), EFF (Cold Leaf Extract), EQR (Hot Root Extract), EFR (Cold Root Extract).

The C. oncocalyx extracts did not affect C. echinatus seedling caulicle length development (Figure 4). However, for radicle development, all extracts had a negative allelopathic effect with bark extracts inhibiting development while the others decreased the length of the structure (Figure 4).

The hot and cold C. oncocalyx bark extracts and cold leaf extracts interfered negatively on C. echinatus seedling caulicle development (Figure 5). In relation to the radicle, the hot and cold bark extracts, hot and cold leaf and hot root extracts affected negatively the development of radicles (Figure 6). 


\section{Cenchrus echinatus}

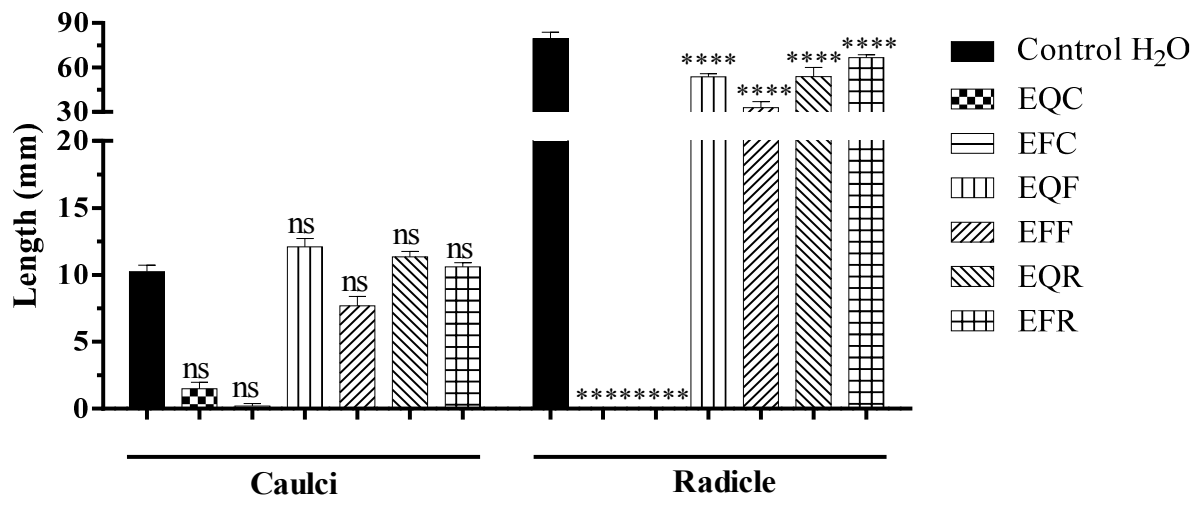

Figure 4. Caulicular and radicular C. echinatus seedling length subjected to C. oncocalyx extracts

Note. Ns: no statistical significance when compared to the control group. $* * * *$ Statistical significance when compared to control. EQC (Hot Bark Extract), EFC (Cold Bark Extract), EQF (Hot Leaf Extract), EFF (Cold Leaf Extract), EQR (Hot Root Extract), EFR (Cold Root Extract).

\subsection{Physico-Chemical Parameters}

The $\mathrm{pH}$ and osmolarity of extracts is important especially when their constitution is unknown for the presence of organic acids, sugars, amino acids and other molecules, as $\mathrm{pH}$ and osmolarity with extreme values can mask the allelopathic effect on seeds and/or target seedlings. However, this was not the case for this study since the $\mathrm{pH}$ values obtained ranging from 6.4 to 7.7 and osmotic potentials ranging from $-0.02 \mathrm{MPa}$ and $-0.09 \mathrm{MPa}$ are in the range adequate for seed germination and seedling development of the host species.

Table 3. Physical-chemical characteristics of the Cordia oncocalyx extracts used in the Cenchrus echinatus and Calotropis procera germination bioassays

\begin{tabular}{lll}
\hline Treatments & pH & Osmolarity Mpa \\
\hline EQC & 6.7 & -0.08631168 \\
EFC & 6.7 & -0.05905536 \\
EQF & 7.7 & -0.09766848 \\
EFF & 7.0 & -0.06586944 \\
EQR & 6.4 & -0.03179904 \\
EFR & 6.5 & -0.0227136
\end{tabular}

Note. EQC (Hot Bark Extract), EFC (Cold Bark Extract), EQF (Hot Leaf Extract), EFF (Cold Leaf Extract), EQR (Hot Root Extract), EFR (Cold Root Extract).

\section{Discussion}

Phytochemical prospection of the extracts allowed the detection of secondary metabolites, such as flavonoids and phenolic acids. Plants can be classified by their secondary metabolites, from which biological and pharmacological activities are attributed. Flavonoids are one of the most important groups due to their biological activities, with the protection against pathogenic microorganisms, antioxidant action, allelopathic action and enzymatic inhibition being among them (Machado et al., 2010; Simões et al., 2000).

Of the compounds identified in the extracts, caffeic acid found in high concentrations in the roots, may be responsible for significantly reducing germination percentage of the recipient monocotyledon, in addition to being reported as a phenylpropanoid that presents allelopathic action (Taiz \& Zeiger, 2017). Barkosky et al. (2000), showed that the coffeic acid is a low molecular weight phenolic compound that has an interesting mechanism of inhibition, this being a water balance rupture of the plant, which affects germination and radicle development. 
Kaempferol, which is the other major root extract constituent, is a flavonoid found in several plants. In allelopathy studies, kaempferol is responsible for the negative effect observed on germination and the development of numerous host species. Such compound, found in greater quantity in the hot $C$. oncocalyx root extract, is possibly responsible for the seed germination delay and C. echinatus seedling radicular growth.

Flavonoids are a class of natural compounds with considerable scientific interest. These are a group of natural substances with variable phenolic structure (Behling et al., 2004). In C. oncocalyx, quercetin was found in the bark extracts, with a greater quantity in the hot extract. Germination, caulicular and radicular length reduction in C. echinatus and C. procera is probably due to quercetin, since Parvez et al. (2004) reported that this flavonoid has allelopathic action. In another species from the same genus, Cordia trichotoma (Vell.) Arráb. ex Steud., which also presents quercetin as one of its major compounds, has an allelopathic effect against Allium cepa $\mathrm{L}$. such that it reduces cell division (Pavanelo, 2014).

Germination velocity delay was also verified by Machado and Pastorini (2014) using C. trichotoma leaf extracts against Lactuca sativa L. seed germination at higher concentrations. These effects are related to the presence of allelochemicals, such as quercetin found in most of the extracts, which retard growth, cell division, nutrient absorption, enzymatic activity and the respiratory chain (Hussain et al., 2011).

\section{Conclusion}

In view of the results of this study, Cordia oncocalyx is a species with allelopathic potential which can be used as a bioherbicide source for the control of C. echinatus in order to decrease the used of synthetic herbicides. Studies focusing on the isolation of the substances found in this plant should be performed in order to identify if the actions found in this study occur synergistically or not.

\section{Acknowledgements}

The Cearense Foundation to Support Scientific and Technological Development (FUNCAP) for financial support, through the Program of Productivity Scholarships in Research, Incentives to Interiorization and Technological Innovation (BPI).

\section{References}

Adefegha, S. A., Oboh, G., Molehin, O. R., Saliu, J. A., Athayde, M. L., \& Boligon, A. A. (2016). Chromatographic fingerprint analysis, acetylcholinesterase inhibitory properties and antioxidant activities of red flower rag leaf (Crassocephalum crepidioides) extract. Journal of Food Biochemistry, 40, 109-119. https://doi.org/10.1111/jfbc. 12292

Ahmed, O. M., Fahim, H. I., Boules, M. W., \& Ahmed, H. Y. (2016). Cardiac and testicular toxicity effects of the latex and ethanolic leaf extract of Calotropis procera on male albino rats in comparison to abamectin. SpringerPlus, 5(1), 16-44. https://doi.org10.1186/s40064-016-3326-7

Alves, M. C. S., Medeiros Filho, S., Innecco, R., \& Torres, S. B. (2004). Alelopatia de extratos voláteis na germinação de sementes e no comprimento da raiz de alface. Pesquisa Agropecuária Brasileira, 39(11), 1083-1086. https://doi.org/10.1590/S0100-204X2004001100005

Barkosky, R. R., Einhellig, F. A., \& Butler, J. L. (2000). Caffeic acid-induced changes in plant-water relationships and photosynthesis in leafy spurge Euphorbia esula. Journal of Chemical Ecology, 26(9), 2095-2109. https://doi.org/10.1023/A:1005564315131

Barroso, I. C. E., Oliveira, F., Branco, L. H. Z., Kato, E. T. M., \& Dias, T. G. (2002). O gênero Cordia L.: botânica, química e farmacologia. Revista Lecta, 20(1), 15-34.

Behling, M. C., Sendão, M. C., Francescato, H. D. C., Antunes, L. M. G., \& Biachi, M. L. P. (2004). Flavonóide quercetina: Aspectos gerais e ações biológicas. Alimentos e Nutrição Araraquara, Araraquara, 15(3), 285-292.

Carvalho, G. J., Fontanétti, A., \& Cançado, C. T. (2002). Potencial alelopático do feijão de porco (Canavalia ensiformes) e da mucuna preta (Stilozobium aterrimum) no controle da tiririca (Cyperus rotandus). Ciência e Agrotecnologia, 26(3), 647-651.

Carvalho, P. E. R. (2008). Pau branco-do-Sertão (Auxemma oncocalyx). Circular Técnica, 153.

Emilio, C., Hoffmann, F., Augusto, L., Bastos, C. F., \& Wallau, G. D. L. (2007). Atividade alelopática de Nerium Oleander L. e Dieffenbachia picta Schott em sementes de Lactuca Sativa L. e Bidens pilosa L. Revista de Ciências Agroveterinárias, 6(1), 11-21. 
Favaretto, A., Scheffer-Basso, S. M., \& Perez, N. B. (2018). Allelopathy in Poaceae species present in Brazil: A review. Agronomy for Sustainable Development, 38, 22. https://doi.org/10.1007/s13593-018-0495-5

Ferreira, A. G., \& Borghetti, F. (2004). Germinação: do básico ao aplicado (p. 323). Porto Alegre: Artmed.

Ferreira, M. A., Nunes, O. D., Fujimura, A. H., Pessoa, O. D., Lemos, T. L., \& Viana, G. S. (1999). Inhibition of platelet activation by quinones isolated from Auxemma oncocalyx Taub. Research Communications in Molecular Pathology and Pharmacology, 106(1-2), 97-107.

Gottschling, M. C., \& Miller, J. S. (2006). Clarification of the Taxonomic Position of Auxemma, Patagonula, and Saccellium (Cordiaceae, Boraginales). Revista Verde, 8(5), 31-39. https://doi.org/10.1600/03636440677758 5919

Guimarães, I. P., Coelho, M. F. B., \& Azevedo, R. A. B. (2013). Pau branco (Cordia oncocalyx Allemão)-Boraginaceae: Árvore endêmica da Caatinga. Revista Verde, 8(5), 31-39.

Hussain, M. I., González, L., Souto, C., \& Reigosa, M. J. (2011). Ecophysiological responses of three native herbs to phytotoxic potential of invasive Acacia melanoxylon, R. Br. Agroforest System, 83(149-166). https://doi.org/10.1007/s10457-011-9433-0

Machado, G. G., \& Pastorini, L. H. (2014). Potencial Fitotóxico de Cordia trichotoma (Vell.) Arrab. Ex Steud (Boraginaceae). Goiânia. Enciclopédia Biosfera, 10(19).

Machado, H., Nagem, T. J., Peters, V. M., Fonseca, C. S., \& Oliveira. T. T. (2010). Flavonóides e seu potencial terapêutico. Boletim do Centro de Biologia da Reprodução, 27(1).

Maguire, J. D. (1962). Speed of germination aid in selection and evaluation for seedling emergence and vigor. Crop Sciense, 2(2), 176-177. https://doi.org/10.2135/cropsci1962.0011183X000200020033x

Maraschin-Silva, F., \& Aqüila, M. E. A. (2006). Contribuição ao estudo do potencial alelopático de espécies nativas. Revista Árvore, 30(4), 547-555. https://doi.org/10.1590/S0100-67622006000400007

Marques, W. B., dos Santos, H. S., Pessoa, O. D., Braz-Filho, R., \& Lemos, T. L. (2000). Anthracene derivatives from Auxemma oncocalyx. Phytochemistry, 55(7), 793-797. https://doi.org/10.1016/S0031-9422(00) 00325-3

Matias, E., Santos, K. K., Falcão-Silva, V. S., Siqueira-Júnior, J. P., Costa, J. G., \& Coutinho, H. D. (2013). Modulation of the norfloxacin resistance in Staphylococcus aureus by Cordia verbenaceae DC. Indian J. Med. Res., 137, 178-182.

Medeiros, R., Passos, G., Vitor, C., Koepp, J., Mazzuco, T., Pianowski, L., ... Calixto, J., (2007). Effect of two active compounds obtained from the essential oil of Cordia verbenacea on the acute inflammatory responses elicited by LPS in the rat paw. Br. J. Pharmacol., 151, 618-627. https://doi.org/10.1038/ sj.bjp. 0707270

Menge, E. O., Greenfield, M. L., Mcconchie, C. A., Bellairs, S. M., \& Lawes, M. J. (2017). Density-dependent reproduction and pollen limitation in an invasive milkweed, Calotropis procera (Ait.) R. Br. (Apocynaceae) Austral Ecology, 42(1), 61-71. https://doi.org/10.1111/aec.12401

Moreira, H. J. C., \& Bragança, H. B. N. (2011). Manual de identificação de plantas infestantes (p. 1017). FMC, SP, 326.

Oliveira, A. K., Coelho, M. F. B., Maia, S. S. S., Diógenes, F. E. P., \& Filho, S. M. (2012) Atividade alelopática de extratos de diferentes partes de juazeiro (Ziziphus joazeiro Mart.-Rhamnaceae). Acta Botanica Brasilica, 26(3), 685-690. https://doi.org/10.1590/S0102-33062012000300018

Oliveira, J. R., Constantin, R. S., J., \& Inoue, M. H. (2011). Biologia e manejo de plantas daninhas (p. 348).

Parvez, M. M., Tomita-Yokotani, K., Fujii, Y., Konishi, T., \& Iwashina, T. (2004). Effects of quercetin and its seven derivatives on the growth of Arabidopsis thaliana and Neurospora crassa. Biochemical Systematics and Ecology, 32(7), 631-635. https://doi.org/10.1016/j.bse.2003.12.002

Pavanelo, L. B. (2014). Potencial antiproliferativo e determinação de compostos fenólicos de Cordia trichotoma (Vell.) Arráb. ex Steud (Dissertation, Federal University of Santa Maria, Rio Grande do Sul, Brazil).

Peres, M. T. L. P., Silva, L. B., Faccenda, O., \& Hess, S. C. (2004). Potencial alelopático de espécies de Pteridaceae (Pteridophyta). Acta Botanica Brasilica, 18(4), 723-30. https://doi.org/10.1590/S0102-3306200 4000400003 
R Core Team. (2014). R: A language and environment for statistical computing. R Foundation for Statistical Computing, Vienna, Austria. Retrieved from http://www.R-project.org

Rice, E. L. (1984). Allelopathy. Academic, Orlando.

Rizzardi, A., Rizzardi, M. A., Lamb, T. D., \& Johann, L. B. (2008). Potencial alelopático de extratos aquosos de genótipos de canola sobre Bidens pilosa. Planta Daninha, 26(4), 717-724. https://doi.org/10.1590/S010083582008000400002

Santos, M. A. F., da Silva, M. A. P., dos Santos, A. C. B., Alencar, S. R., Torquato, I. H. S., Andrade, A. O., ... de Oliveira, A. H. (2015). Allelopathy of Miconia spp. (Melastomataceae) in Lactuca sativa L. (Asteraceae). Journal of Agricultural Science, 7(12), 151. https://doi.org/10.5539/jas.v7n12p151

Simões, C., Schenkel, E.P.; Gosmann, G., Mello, J. C. P., Mentz, L. A., \& Petrovick, P. R. (2000). Farmacognosia da planta ao medicamento (2nd ed.). Porto Alegre, Florianópolis: Ed. Universidade/ UFRGS; Ed. Universidade/UFSC.

Souza-Filho, A. P. S., Borges, F. C., \& Santos, L. S. (2006). Análise comparativa dos efeitos alelopáticos das substâncias químicas titonina e titonina acetilada. Planta Daninha, 24(2), 205-210. https://oi.org/10.1590/ S0100-83582006000200001

Taiz, L., \& Zeiger, E. (2017). Fisiologia Vegetal (5th ed., p. 820). Porto Alegre: Artmed.

Zeng, W., Jiang, N., Nadella, R., Killen, T. L., Nadella, V., \& Faik, A. (2010). A glucurono(arabino)xylan synthase complex from wheat contains members of the GT43, GT47, and GT75 families and functions cooperatively. Plant Physiol., 154, 78-97. https://doi.org/10.1104/pp.110.159749

\section{Copyrights}

Copyright for this article is retained by the author(s), with first publication rights granted to the journal.

This is an open-access article distributed under the terms and conditions of the Creative Commons Attribution license (http://creativecommons.org/licenses/by/4.0/). 